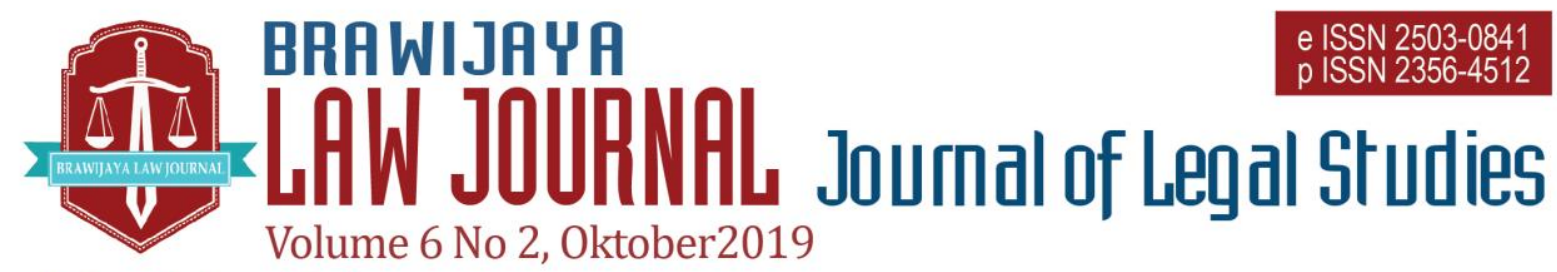

Nationally Accredited No. 30/E/KPT/2018 Dated 24th October 2018

This work is licensed under a Creative Commons Attribution-NonCommercial 4.0 International License

\title{
Restorative Justice: an Alternative Process for Solving Juvenile Crimes in Indonesia
}

\author{
Mahfud Jufria, Norbani Binti Mohamed Nazeri ${ }^{\mathrm{b}}$, Saroja Dhanapal ${ }^{\mathrm{c}}$ \\ ${ }^{a}$ Faculty of Law, University of Malaya, Malaysia \\ Email: mahfudsh@yahoo.com \\ ${ }^{b}$ Faculty of Law, University of Malaya, Malaysia \\ Email: norbanim@um.edu.my \\ ${ }^{\mathrm{c}}$ Faculty of Law, University of Malaya, Malaysia \\ Email: saroja.dhanapal@um.edu.my
}

Submitted : 2019-03-01 | Accepted : 2019-08-16

\begin{abstract}
Restorative justice concept may refer to an alternative process for solving disputes including criminal law violation has been well known in Indonesia. The Act Number 11, 2012 on Juvenile Justice System has acknowledged restorative justice approach as a part of criminal justice system in dealing with a child in conflict with the law. It has become an essential provision in the Act as it provides option for law enforcers to avoid punishing juvenile offenders through traditional criminal approach. This research aims to examine restorative justice for juvenile offenders in Indonesia based on the Juvenile Justice System Act Number 11, 2012 as a form of alternative dispute resolution for juvenile crimes and other related laws and to provide a brief of the implementation of restorative justice in Indonesia that is integrally enforced in Indonesian criminal justice system dealing with a child in conflict with the law. It divides the discussion into two parts restorative justice in the juvenile justice system act 2012 and the implementation of restorative juvenile justice in Indonesia. In order to response to these research aims, this paper employs doctrinal legal research.
\end{abstract}

Keywords: restorative justice; alternative process; juvenile crimes; Indonesia.

\section{INTRODUCTION}

The concept of restorative justice may refer to an alternative process for solving disputes, to alternative sanctioning options, or to a distinctively different, new model of criminal justice organized around principles of restoration to victims, offenders and the

1 Theo Gavrielides, 'Restorative justice-the perplexing concept: isepepiConceptual fault-lines and power battles within the restorative justice communities in which they live. ${ }^{1}$ The most popular definition of restorative justice is offered by Marshall, who defines it as "a process whereby all parties with a stake in a particular offence come together to resolve collectively how to deal with the aftermath of

movement' (2008) 8(2) Criminology and Criminal Justice 165,166. doi: 10.1177/1748895808088993 
the offence and its implications for the future". 2

Conflict resolution reflects the processes of social and relationship, with children who are able to solve disputes in amicable ways having a bigger opportunity of getting involved in friendships and achieving peer acceptance. ${ }^{3}$ In addition, family mediation has been widely used to help parents agree on issues regarding their children and teachers in schools introduce training programs to empower pupils' skills to overcome conflict. ${ }^{4}$ Moreover, alternative dispute resolution is not only refereed to a simply dispute resolution, but it is also referred to additional traditional dispute resolution by litigation, or particularly, to adjudication by a court. ${ }^{5}$ It is clear that an alternative dispute resolution such as restorative juvenile justice approach that has been incorporated in the Indonesian Act Number 11, 2012 on Juvenile Justice System Act (later called as the JJS Act 2012) is potentially effective in dealing with a child in conflict with the law because it recognizes that the best interest of the child should come first in dealing with a child committing crime.

Restorative justice goals are to empower victims, communities, offenders and families to restore the effects of a harmful event, using effective remorse ceremony. ${ }^{6}$ Few aspects of restorative justice has been legislated in the existing Indonesian laws, namely; the Child Protection Act Number 23, 2002 stipulating that criminal

2 Tony F. Marshall, Restorative Justice: An Overview. (London: Home Office, 1999), pp. 5

3 Nicole Ashby and Cathrine Neilsen-Hewett, 'Approaches to conflict and conflict resolution in toddler relationships' (2012) 10(2) Journal of Early 145, 147.

4 Cristina A. Palma, 'Conflict resolution in community development: Are the benefits worth the costs?' (n.d.) Critical Social Policy 1, 3.

5 Allison Ballard and Patricia Easteal, courts are the last resort for handling juvenile delinquency which is in accordance with the United Nations Convention on the Rights of the Child and the Human Rights Act Number 39, 1999 wording that trial of courts is the least choice in dealing with a juvenile offender. ${ }^{7}$ Presently, the most important law in regard with the juvenile criminal justice system is the JJS Act 2012, which has changed the Indonesian legal system dealing with juvenile offenders progressively. ${ }^{8}$

Article 1 (1) and (2) of the JJS Act 2012 provides that:

Juvenile Justice System is a whole juvenile justice process, which is started from pre-investigation to post correctional service stages, and the scope of this Act is not only a child in conflict with the law (a child who commit crime) but also a child as a witness and a victim.

In regard with the definition of restorative justice in the JJS Act 2012, Article 1(6) states that:

Restorative justice is a crime settlement by involving, victims, offender or victim families, and other relevant parties to solve a case justly by focusing on rehabilitative approach and to avoid revenge.

In the explanation of the Act, it provides that the restorative justice is a part of diversion process in which all parties get involved in a particular crime cooperatively solve a case and create an obligation to put things better by involving victims, child,

'(Alternative) Dispute Resolution and Workplace Bullying, Some pros and cons from the coalface' (2016) 41(2) Alternative Law Journal 105, 105.

6 Fathillah A. Syukur, Dale M. Bagshaw, 'VictimOffender Mediation with Youth Offenders in Indonesia' (2015) 32 (4) Conflict Resolution Quarterly 390, 393.

7 Ibid.

$8 \quad$ Ibid, 391 
community in order to find solution to restore, reconcile peacefully which is not based on revenge.

Article 1 (2) of the Government Regulation of Republic Indonesia Number 65, 2015 on the Guidance of Diversion Implementation and Action towards a Child under 12 Years Old defines restorative justice as a process to solve a crime by involving an offender, a victim, families of a child and a victim and other related parties to collectively solve a crime fairly by focusing on restoring, and not a revenge. The definitions provided by both the JJS Act 2012 and the Government Regulation of Republic Indonesia Number 65, 2015 on the Guidance of Diversion Implementation and Action towards a Child under 12 Years Old seems not complete yet because it has not included how to deal with the aftermath of the offence and its implications for the future as what has been proposed by Marshall above.

This paper is going to examine restorative justice for juvenile offenders in Indonesia based on the JJS Act 2012 and other related laws and to provide a brief of the implementation of restorative justice in Indonesia that is integrally enforced in Indonesian criminal justice system dealing with a child in conflict with the law.

\section{LEGAL MATERIALS AND METHODS}

This research employs a doctrinal research. The term of doctrinal used here is to refer to "legal concepts and principles of all types - cases, statutes, rules". ${ }^{9}$ Doctrine has been described "as a synthesis of rules, principles, norms, interpretive guidelines and values". ${ }^{10}$ Doctrinal research is also referred

\footnotetext{
$9 \quad$ Terrry Hutchinson and Nigel Duncan, 'Defining and Describing What We Do: Doctrinal Legal Research' (2012) 17(1) Deakin Law Review 83, 84. 10 Ibid.
}

to as pure legal research, which is essentially a library-based study meaning that the materials needed by a researcher may be available in libraries, archives and other databases. ${ }^{11}$ The research will fundamentally involve the critical analysis of material from both primary and secondary sources. Primary sources comprise legislation, regulations and rules, conventions, treaties and cases. Apart from primary sources, secondary sources comprise textbooks, journal articles, legal encyclopedias, seminar papers, newspapers and official websites. These will be referred in order to update law development, recent issues, academic discussion, data and other relevant information and knowledge on this subject

\section{RESULT AND DISCUSSION Restorative Justice in the Juvenile Justice System Act 2012}

Article 5 (1) of the JJS Act 2012 states that juvenile justice system must prioritize restorative justice approach. The approach is very essential for the diversion process. It can be seen from Article 8 of the JJS Act 2012 providing that:

The diversion process is conducted through a meeting to involve juvenile offenders and or their parents or guardians, victims and or their parents or guardians, probation officers and professional social workers by the approach of restorative justice, and it must be made in all criminal proceeding stages of juvenile cases, from investigation to trial stages, the provision is clearly stating that the

11 Anwarul Yaqin, Legal Research and Writing, (Malaysia, Malayan Law Journal SDN BHD. 2007), pp. 10 
diversion process must be done by the restorative justice approach.

In response to the diversion in the JJS Act 2012, the Indonesian Government has enacted the Government Regulation of Republic Indonesia Number 65, 2015 on the Guidance of Diversion Implementation and Action towards a Child under 12 Years Old. Article 5 (2) of the Government Regulation states that if it is necessary the diversion process might involve social welfare workers and or community.

In addition, the Indonesian Supreme Court responds the implementation of the JJS Act 2012 by issuing its Regulation Number 4, 2014 on the Guidance of Diversion Implementation in Juvenile Justice System. It has incorporated the need of restorative juvenile justice approach in holding diversion towards juveniles in Indonesia. Article 1 (1) of the Regulation provides that diversion conferencing is a meeting among parties of juvenile and the parents/guardian, victim and/or the parents/guardian, probation officers, professional social worker, representatives of communities and other parties having interest in this case in order to reach diversion through restorative justice approach.

Ferry Fathurokhman views that from the Indonesia's legal culture, the restorative justice approach is basically similar to musyawarah. ${ }^{12}$ In addition, John Braithwaite In addition, has explored gotong royong (joint bearing of burdens), as an Indonesian

12 Ferry Fathurokhman, 'The necessity of restorative justice on juvenile delinquency in Indonesia, lessons learned from the Raju and AAL cases' (2013) 17 Procedia Environmental Sciences 967, 973

13 John Braithwaite, 'Traditional Justice'. In Llewellyn, J. J. \& Philpott, D. (eds.), Restorative Justice, Reconciliation and Peacebuilding (New York, United States of America: Oxford University Press, 2014) 214, 239.

14 Fathurokhman, F., above n 12, 971. philosophy should be applied in restorative justice and reconciliation processes. ${ }^{13}$ Moreover, Ferry Fathurokhman also claims mufakat as the outcome of the musyawarah process and the collective agreement. ${ }^{14}$ Furthermore, Indonesian are keenly to participate in the case of a child in conflict with the law through restorative justice. ${ }^{15}$

As restorative justice processes intrinsically resemble to musyawarah in Indonesia's legal tradition, as what has been claimed by Ferry Fathurokhman above, it has become a tool in settling the diversion in Indonesian JJS Act 2012. It is clearly worded in Article 8 of the JJS Act 2012 which states that the diversion process is conducted through a meeting to involve juvenile offenders and or their parents or guardians, victims and or their parents or guardians, probation officers and professional social workers by the approach of restorative justice, and it must be made in all criminal proceeding stages of juvenile cases, from investigation to trial stages, the provision is clearly stating that the diversion process must be done by the restorative justice approach.

In addition, Article 8 (2) of the JJS Act 2012 allows the involvement social welfare workers and or community in the diversion processes if it is needed. ${ }^{16}$ This Article is similar to Article 5 (2) of the Government Regulation of Republic Indonesia Number 65, 2015 on the Guidance of Diversion Implementation and Action towards a Child under 12 Years Old. It means presently that

15 Nur Rochaeti and Pujiyono Pujiyono, 'The Implementation Study of Restorative Justice for Juvenile Criminal Justice System by Customary Court in Mainland Sulawesi' (2018) 156 Proceedings of Earth and Environmental Science, IOP Conference Series IOP Publishing 1, 4.

16 Article 5 (2) of the Government Regulation of Republic Indonesia Number 65, 2015 on the Guidance of Diversion Implementation and Action towards a Child under 12 Years Old 
the participation of social welfare workers and or community in the diversion processes is not compulsory.

Moreover, due to the fact that restorative justice is a key in implementing the diversion, Article 8 (3) of the JJS Act 2012 provides the basic values of restorative juvenile justice. These are namely; victim's interest, the welfare and responsibility of juvenile offender, non-stigmatization towards the offender, non-revenge, community harmony, properness, humility and public safety.

Furthermore, Article 9 (1) of the JJS Act 2012 provides that in the diversion process police, a prosecutor and a judge have to consider a crime category, child's age, a probation officer report and the support from the family. Article 9 (2) of the Act clearly states that only a victim and or victim's family must agree to the diversion outcomes and the juvenile and the juvenile's family must agree with the outcomes. It is clear that encounter conception, as has been proposed by Johnstone and Van Ness, ${ }^{17}$ in the Indonesian JJS Act 2012 is not recognized in regards with reaching the diversion decision.

The possibility of involvement of other parties who are outside of a child and a victim of a crime and their families and formal law enforcers in the diversion process, is only when it is considered necessary, it is not obligatory.

However, the consent aforementioned might be ignored by police if a crime is not serious or misdemeanor, a crime is without

17 Johnstone, G. \& Van Ness, D.W., 'The Meaning of Restorative Justice' In G. Johnstone \& D.W. Van Ness (Eds.), Handbook of Restorative Justice, (Oregon USA: Willan Publishing, 2007) 5, 23.

18 Art. 9 (2) of the JJS Act 2012

19 Art 10 (1) of the JJS Act 2012

20 Johnstone, G. \& Van Ness, D.W. above n 17, 17

21 Rusmilawati Windari and Ermania Widjajanti, 'The double track system in sentencing juvenile the victim, and the amount of the victim's lost is not more than the regional minimum wage. ${ }^{18}$ The police might involve a child and a victim of a crime and their families, probation officer and community leaders. ${ }^{19}$ Article 93 (d) of the JJS Act 2012 regulates the participation of community in solving a juvenile case in the process of diversion and restorative justice.

In regard with reparative conception, as one of the concepts offered by Johnstone and Van Ness, ${ }^{20}$ Article 10 of the JJS Act 2012 provides that the outcomes of the diversion might be financial restoration of a victim, medical and psychosocial rehabilitation, returning offenders to their parents or guardians, involving offenders in education or training program at educational institution or Special Institution for Children Treatment (LPKS) or community service for a maximum of three months. In addition, the JJS Act 2012's sentencing system is a double track system because it has sentences and treatment or action. ${ }^{21}$ One of the treatments in Article 82 (1) is restoring criminal losses as the sign of restorative justice in the treatment sanction of the JJS Act 2012. ${ }^{22}$

\section{The Implementation of Restorative Juvenile Justice in Indonesia}

The JJS Act 2012 has clearly stated that restorative justice is a key in implementing diversion, which is aiming at conducting a restorative approach between the child and a victim of crime. ${ }^{23}$ However, a juvenile is not eligible to be put into the diversion process if

offenders in Indonesia: Strengths and weaknesses of the Juvenile Criminal Justice System Act 2012' (2015) 23(3) IIUM Law Journal, 501, 524.

22 Ibid, 512

23 Putri K. Amanda, 'Juvenile Sex Offender Rehabilitation: How the Us Approach Can Help Indonesia Satisfy Its Commitment To Restorative Justice Principles' (2014) 4 Indonesia Law Review $86,93$. 
a child commits a crime with charge of 7 (seven) years of imprisonment and the status of the offender is not a recidivist. ${ }^{24}$ Thus, a child committing a serious offense, such as sexual offenses is not going to be diverted as because the maximum imprisonment for these violations is between 12 (twelve) and 15 (fifteen) years. ${ }^{25}$ It seems that restorative justice is likely to be successful if a juvenile case is successful to be diverted.

It can be said that the success of restorative justice approach seems to be mostly depended on succeeded diversion process which can be found in Article 1(6) of the JJS Act 2012 and its explanation which provides that the restorative justice is a part of diversion process in which all parties get involved in a particular crime cooperatively solve a case and create an obligation to put things better by involving victims, child, community in order to find solution to restore, reconcile peacefully, not revenge.

However, the JJS Act 2012 does not limit the implementation of restorative justice only along with the diversion process in which must be attempted in the levels of police investigation, prosecution and trial. Article 5 (2) (c) It has clearly mentioned that the approach of restorative justice in Indonesian juvenile justice system must be a priority including in the levels of guidance, monitoring, and/or education during serving a sentence or action and after serving a sentence or action.

In other words, restorative justice approach in the JJS Act 2012 might still possible to be implemented when a juvenile

\footnotetext{
Ibid, 94

25 Ibid, 94

26 Y. T. Wangi, 'Policy of Development for Juvenile Delinquency in the Perspective of Indonesian Criminal Justice System Reform (Study on Institute for Special Development Children LPKA Kutoarjo, Central Java, Indonesia)' (2017) 2, JILS $85,92$.
}

serving a sentence or action if diversion attempts by police, a prosecutor and a judge failed. In addition, the approach is not going to be void if the attempt of diversion process fails. It can be seen that the JJS Act 2012 aims at restoring or trying to put things right from investigation level to post-sentencing of a juvenile. Indonesian juvenile criminal justice system is seen as the non-separated system from the level of police investigation to the enforcement of the juvenile court decision. ${ }^{26}$ The diversion aims which are in line with restorative justice approach namely to reach a peace between a victim and a juvenile, to encourage community to participate and to avail the awareness of responsibility towards a juvenile are still possible to be implemented when a convicted juvenile serving a sentence or an action. ${ }^{27}$

As restorative justice approach becomes a key in implementing a diversion process at the levels of investigation, prosecution and trial, the compulsory diversion effort at each level of juvenile criminal investigation is very essential. It means that every responsible officer in every stage of those criminal proceedings must seek diversion agreement. ${ }^{28}$ The JJS Act 2012 has limited the police and the prosecutor to complete diversion effort within 7 (seven) days since they receive a dossier of the juvenile offender. 29 Surprisingly, both the JJS Act 2012 and the Supreme Court Regulation Number 4, 2014 do not provided the limit of a diversion effort process limit for a juvenile court. Nevertheless, it has been ruled in Article 51

27 Art. 6 the JJS Act 2012

28 Loura Hardjaloka, 'Criminal Justice system of Children: an overview Restorative Justice Concept in Indonesia and Other Countries' (2015) 15(1) Jurnal Dinamika Hukum 73, 76.

29 Arts. 29 (1), 42 (1) of the JJS Act 2012 
(1) of the Government Regulation of Republic Indonesia Number 65, 2015 on the Guidance of Diversion Implementation and Action towards a Child under 12 Years Old which states that the effort must be completed within 30 (thirty) days since a court begins the effort. In practice, either in investigation, prosecution, or trial level, the diversion effort is conducted no more than twice. $^{30}$

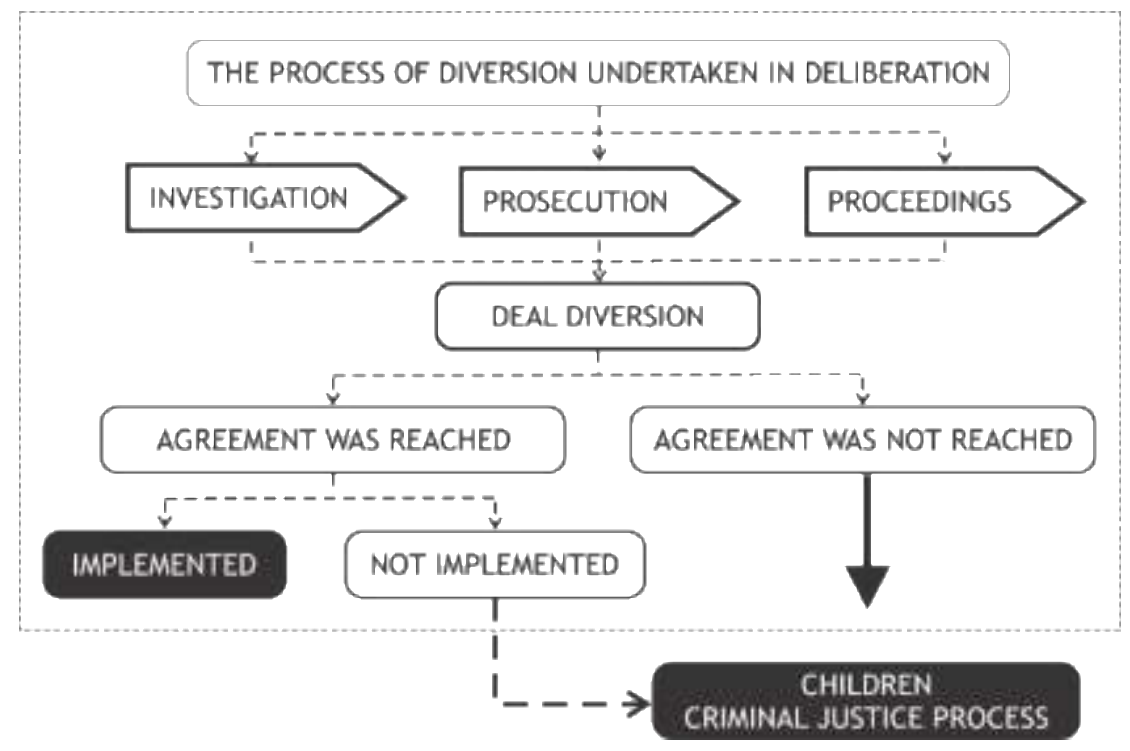

Source: Loura Hardjaloka, 2015.

Despite the fact that Indonesia has already incorporated restorative justice approach in its JJS Act 2012, the implementation of restorative juvenile justice in Indonesia still shows poor performance. ${ }^{31}$ It can be seen from the percentage of juvenile offenders that have been imprisoned is still high with about $90 \% .{ }^{32}$ In addition, there is also the finding that despite restorative justice and diversion have been incorporated in the JJS Act 2012, the Juvenile Court still considers that imprisonment is the merely option for the boys. ${ }^{33}$ However, some claim that the customary court existence is still believed that implementing of restorative

30 I. Karangan, 'Implementation of Law Number 11 of 2012 Concerning Child Related Criminal Justice System Concept Restorative Justice' (2016) 1(1) Pattimura Law Journal 67, 74.

31 Abdul Syukur, F., Bagshaw, D.M., above n 6, 396

32 Ibid.

33 Sharyn G. Davies, and Jazz Robson, 'Juvenile (In) justice: Children in Conflict with the Law in Indonesia' (2016) 17 Asia-Pacific Journal On justice approach has been familiar with the people. $^{34}$

It has been claimed that the JJS Act 2012 has provided a legal basis for implementing victim-offender mediation (VOM) as a form of restorative justice approach in handling juvenile offenders. ${ }^{35}$ VOM as one of the restorative justice models discuses and resolves the offence by focusing on condemning the act not the offender. ${ }^{36}$ The discussion may lead to offender or family or friends to experience the shame of the act and prompting apology to victim. ${ }^{37}$

In the JJS Act 2012, VOM can be said as one form of the diversion processes that

Human Rights and the Law 119, doi 10.1163/15718158-01701009, 146.

34 Nur Rochaeti and Pujiyono Pujiyono. Above n 15, 3.

35 Ibid, 392

36 Norbani Mohamed Nazeri, Restorative Justice: Definition and Concept [Lecture Power Point Slide] (2018).

37 Ibid. 
must be held either by police, prosecution office or court if the case is eligible for being diverted. Thus, each officer in every criminal process level above is responsible for being a mediator. Diversion processes do not only hold a meeting to involve juvenile offenders and victims but also involve guardians, probation officers and professional social workers by the approach of restorative justice. However, the JJS Act 2012 is not clear about who should be a mediator in every criminal process level as the Act only stipulates the criteria that must be fulfilled by those officers in dealing with juvenile offenders. ${ }^{38}$ In addition, it seems that a mediation process only can be held in the court because the court has a special room for conducting mediation. ${ }^{39}$

Interestingly, in regard with VOM issue, the Indonesian judicial administration system in dealing with juvenile offenders is one step more advanced than criminal administration processes at the police and the prosecution office levels. It results from the issuance of the Indonesian Supreme Court Regulation Number 4, 2014 on the Guidance of Diversion Implementation in Juvenile Justice System by the Indonesian Supreme Court. The mediator is known as facilitator who is appointed by the General Court in Chief having an authority too handle a juvenile case. ${ }^{40}$

VOM is conducted after the trial starts by conveying the basic of VOM as a tool of restorative justice aiming to restore the relationship between the parties ${ }^{41}$ Before commencing the VOM, the mediator and the parties should establish that all required

8 Arts. 26, 41, 43 of the JJS Act 2012

Art. 52 (4) of the JJS Act 2012

40 Art. 1 (2) the Indonesian Supreme Court Regulation Number 4, 2014

41 Fatahillah A. Syukur and Dale M. Bagshaw, above n 6, 401 information must be shared in the meeting; everyone must not interrupt, accuse, insult other parties when they are talking; and each party must control any strong and negative emotion. ${ }^{42}$ In addition, the nature of the VOM is the repentance from an offender to a victim. $^{43}$

The following is the case study of jewelry stealing involving a youth offender, which is solved through VOM. The offender is a sixteen-year-old boy living with his parents. He is the couples' only child. The family is poor, and the parents work all day to fulfill their basic needs. The father is a fisherman and the mother is a housemaid. The family can only provide once meal a day and the juvenile offender quit his education due to economic condition. ${ }^{44}$ The offender is looking for some money to buy his birthday by stealing jewelry from his wealthy neighbor resulting in the offender being arrested for larceny. Based on Indonesian criminal law, stealing can be maximally sentenced to five years of imprisonment. As the perpetrator is a child, he can only be sentenced maximally half of adult's maximum charge. The police and the prosecutor convince the victim to forgive the offender because he is a first time offender. However, the victim disagrees with this because his property has been stolen, and the offender is the suspect. The case is tried before to the district court. ${ }^{45}$

On the first day of trial, the offender made plea guilty to the stealing and he asked for forgiveness from the judges' chamber, as it is his first commission. In addition, the offender regretted what he had done and 
promised that he would not repeat another crime. Moreover, He wished to continue his education and to have a better future. Having listened to his plea and considered the JJS Act 2012 allowing a conditional sentence without prison serving, the judges' chamber convinced the parties, the plaintiff, and the defendant to get involved in a victimoffender mediation process. The victim, who initially disagrees with this, agrees to take up this offer after being persuaded by some prominent leaders in the community, who vouched that the offender had never conducted any previous offenses. ${ }^{46}$

The VOM is conducted in the mediation room and presented by the chief of the judges' chamber (acting as mediator), the probation officer, the prosecutor, the plaintiff, the defendant, the defendant's parents, and a leader of community. The mediator commenced the process by asking everybody to pray together before conveying the goals of the mediation and establishing some fundamental rules with both parties. ${ }^{47}$ It provides victim an opportunity to tell the case first and wished that his farm and property were safe followed by the offender's and his family remorse and promise not to reoffend the crime. The probation officer suggesting him to be returned to his family supports his plea. The parents promised that they would pay more attention with him and monitor his activities. The community leader urged everybody to keep harmony in society and protect the offender's future. He promised to keep society peace together with other village leaders as well as he asked the victim to contribute. ${ }^{48}$ The parties were able to come to an agreement. The victim accepted the apology and said that he expected the offender's parents to pay more attention on the offender's behavior. The mediator took this agreement in making consideration to the judicial chamber for their final decision. They concluded to release the offender and to return him to his parents, to order supervision from a probation officer until he becomes adult, and to order him to return the jewelry that he stole." ${ }^{49}$

This case demonstrates that it is essential to have an open legal apparatus caring about the future of juvenile offenders who concede he is guilty of committing crime. All of the law enforcers and the probation officer concerned to the case background of the case and suggested a restorative justice approach in settling the case harmoniously. The offense type, the offender age and prior criminal record, harm it caused, the plea of the offender, offender's repentance, and probationary reports and recommendation are the criteria that are considered before the VOM to be held. ${ }^{50}$ In addition, the community's role is very essential in the implementation of restorative justice, and it will be unsuccessful without such role. ${ }^{51}$

The last sentence of the juvenile case story solved through VOM above that "They decided to release the offender from prison back to his parents, ordered supervision from a penitentiary officer until he reached adult age, and ordered him to return the stolen jewelry" means that the case was settled by using the JJS Act 2012 in which the supervision has been incorporated in the Act. ${ }^{52}$ In addition, in this case, the offender is also ordered to return the stolen jewelry, in which the JJS Act 2012 also has ruled this

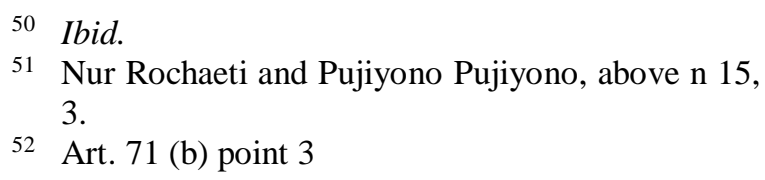

46 Ibid, 404

47 Ibid.

48 Ibid.

49 Ibid, 405 
kind of VOM outcome. ${ }^{53}$ Moreover, despite in this case the juvenile offender is not obliged to perform "Kewajiban Adat" or customary obligation, the JJS Act 2012 surprisingly has also incorporated this obligatory Adat fulfillment. ${ }^{54}$

It can be concluded that the JJS Act 2012 has accommodated the important values of restorative justice approach based on the cultural values living among Indonesian people that is musyawarah which is prioritizes the values of voluntariness, truth telling, a-face-to-face encounter, restoring the harm caused by the crime and repentance. Having these traditional values acknowledged by the JJS Act 2012 it can be said the JJS Act 2012 is in accordance with the Indonesian traditional values. Despite the fact that Indonesia is the multi-ethnicities country, imposing restitution in the form of restoration has been a part of restorative justice approach in the country because restorative justice sees the main victim is not the state, but it is the individual which then results in the offender being responsible to put things right which is one of these is restoration toward a victim. ${ }^{55}$

There is the fact that the successfulness of the restorative justice implementation as the juvenile criminal justice system in Indonesia based on the JJS Act 2012 strongly depends on whether the community still keeps their traditional values or not. The study on certain areas in Indonesia that the communities still preserve their customary laws shows that the implementation of restorative juvenile justice of the JJS Act

\footnotetext{
Art. 71 (2) verse a

Art. 71 (2) verse b

55 Nur Rochaeti, 'Legal Culture of Restorative Justice in Juvenile Criminal Justice System in Indonesia' (2016) 84 Proceedings of Advances in Social Science, Education and Humanities Research International Conference on Ethics in Governance (ICONEG), Atlantis Press.
}

2012 has been successful. ${ }^{56}$ Nevertheless, another study also shows that restorative juvenile justice in the JJS Act 2012 has not been optimally implemented in certain area, for instance in Medan municipality, due to a variety of ethnic which has its own characteristics and social bound in the group. ${ }^{57}$

In Aceh adat has "a perceived legitimacy that was potentially useful in a post-conflict environment". ${ }^{58}$ However, nowadays, for certain area in Indonesia such as Aceh, it seems there are no consistency between the society belief in customary law or adat and the successfulness of restorative juvenile justice implementation based on the JJS Act 2012. It is evidenced by the report of probation officer at the Probation Office of the Branch of the Ministry of Law and Human Right Banda Aceh provided details on an email and we acted based on that information. It reveals that from 2016 to 2016 the total numbers of probation reports' demands to divert juvenile offenders are 412. In fact, only 165 of juvenile offenders' cases are successful to be diverted. It means that a perceived customary law or adat might ease to implement restorative juvenile justice is not always true. It seems that there are also other aspects might have influence on the implementation of restorative justice for juvenile offenders in regard with the JJS Act 2012, such as the paucity of probation officers and uncommon perception among law enforcers.

Aside from holding the VOM as a part of restorative justice process in the trial

56 Rochaeti, N., Pujiyono, P., above n 15, 6.

57 Rochaeti, N., above n 55

58 Cynthia M. Horne, 'Reconstructing 'traditional'justice from the outside in: Transitional justice in Aceh and East Timor' (2014) 9(2) Journal of Peacebuilding \& Development 17, 23. 
process of the Juvenile Court in Indonesia, the JJS Act 2012 also provides the Community Service Order as one of the conditional sentences, which is under the category of the main criminal sanction. ${ }^{59}$ This kind of punishment is unprecedented in the sorts of criminal sanction in Indonesia. Community Service is deemed as one of the restorative justice programs as the principle under the community service is to reintegrate the offenders back to community. ${ }^{60}$ However, this kind of punishment is not preferable for the court to decide. It seems that there has not been clear procedure made yet in regard with implementing such punishment.

\section{CONCLUSION AND SUGGESTION}

To conclude, unprecedentedly, restorative juvenile justice has been a part of the Indonesian criminal justice system, which is legislated in the JJS Act 2012 as juvenile criminal justice system act. The JJS Act 2012 has incorporated restorative justice as a key in implementing diversion; this is an obligatory effort to be conducted by the law enforcers of the JJS Act 2012. However, to divert a juvenile offender must be fulfilled two criteria namely, the crime is charged with imprisonment below 7 (seven) years and the offender is not a recidivist.

The implementation of restorative juvenile justice of the JJS Act 2012 in Indonesia begins from police to trial before the court in terms of its application under diversion process, and as well as it may extend to post-sentencing. VOM as one of its models has been a familiar process for Indonesian because VOM has embedded the Indonesian values of musyawarah, mufakat and gotong royong. The values have been

59 Art. 71 (1) b (2) of the JJS Act 2012

60 Azman, A., and Mohammad, M. T., Crime Victims Support System and Restorative Justice: Possible living as Indonesian culture, as customs or Adat, before the implementation of the JJS Act 2012. However, in this modern era, the way of the people thinks about these values might change that results in not all Indonesian agree with the approach of restorative justice for juvenile offenders. Some consider that it results from weak customary law influences in the society and social bonds. Restoring harms affected by juvenile offenders might be going smoothly in the community with prevailing to use local wisdom values although it might not happen if there are paucity of law enforcers and their uncommon views on this approach. Community service, which has been worded in the JJS Act 2012 and considered to be one of the means of restorative justice approach, has not shown substantial contribution towards the victims, offenders and the community so far. Further research is needed in terms of evaluating the JJS Act 2012 provision of providing restorative justice based on the based models of its implementation such as New Zealand model which is renowned as one of the best modern restorative justice models.

\section{REFERENCES}

\section{Books}

Braithwaite, John, 'Traditional Justice'. In Llewellyn, J. J. \& Philpott, D. (eds.), Restorative Justice, Reconciliation and Peacebuilding (New York, United States of America: Oxford University Press, 2014) 214.

G., Johnstone, D.W., Van Ness, 'The Meaning of Restorative Justice' In G. Johnstone \& D.W. Van Ness (Eds.), Handbook of Restorative Justice, of Arts and Humanities 18, 22. 
(Oregon USA: Willan Publishing, 2007).

Marshall, Tony F., Restorative Justice: An Overview. (London: Home Office, 1999).

Yaqin, Anwarul, Legal Research and Writing, (Malaysia, Malayan Law Journal SDN BHD. 2007).

\section{Journals}

Amanda, Putri K., 'Juvenile Sex Offender Rehabilitation: How The Us Approach Can Help Indonesia Satisfy Its Commitment To Restorative Justice Principles' (2014) 4 Indonesia Law Review 86.

Ashby, Nicole, and Neilsen-Hewett, Cathrine, 'Approaches to conflict and conflict resolution in toddler relationships' (2012) 10(2) Journal of Early 145.

Azlinda, Azman and Mohdammad, Mohd. T., Crime Victims Support System and Restorative Justice: Possible Implementation in Malaysia' (2012). 1(2) Journal of Arts and Humanities 18. Ballard, Allison and Easteal, Patricia, '(Alternative) Dispute Resolution and Workplace Bullying, Some pros and cons from the coalface' (2016) 41(2) Alternative Law Journal 105.

Davies, Sharyn G. and Robson, Jazz, 'Juvenile (In) justice: Children in Conflict with the Law in Indonesia' (2016) 17 Asia-Pacific Journal On Human Rights And The Law 119, doi 10.1163/15718158-01701009.

Fathurokhman, Ferry, 'The necessity of restorative justice on juvenile delinquency in Indonesia, lessons learned from the Raju and AAL cases' (2013) 17 Procedia Environmental Sciences 967.
Gavrielides, Theo, 'Restorative justice - the

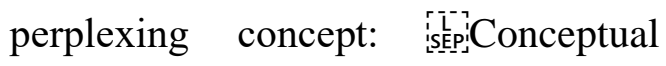
fault-lines and power battles within the restorative justice movement' (2008) 8(2) Criminology and Criminal Justice 165. doi: 10.1177/1748895808088993.

Hardjaloka, Loura, 'Criminal Justice system of Children: an overview Restorative Justice Concept in Indonesia and Other Countries' (2015) 15(1) Jurnal Dinamika Hukum 73.

Horne, Cynthia M., 'Reconstructing 'traditional'justice from the outside in: Transitional justice in Aceh and East Timor' (2014) 9(2) Journal of Peacebuilding \& Development 17.

Hutchinson, Terrry and Duncan, Nigel, 'Defining and Describing What We Do: Doctrinal Legal Research' (2012) 17(1) Deakin Law Review 83.

Karangan, I., 'Implementation of Law Number 11 of 2012 Concerning Child Related Criminal Justice System Concept Restorative Justice' (2016) 1(1) Pattimura Law Journal 67.

Norbani Mohamed Nazeri, Restorative Justice: Definition and Concept [Lecture Power Point Slide] (2018).

Nur Rochaeti, 'Legal Culture of Restorative Justice in Juvenile Criminal Justice System in Indonesia' (2016) 84 Proceedings of Advances in Social Science, Education and Humanities Research International Conference on Ethics in Governance (ICONEG), Atlantis Press.

Palma, Cristina A., 'Conflict resolution in community development: Are the benefits worth the costs?' (n.d.) Critical Social Policy 1.

Rochaeti, Nur and Pujiyono, Pujiyono, 'The Implementation Study of Restorative Justice for Juvenile Criminal Justice System by Customary Court in 
Mainland Sulawesi' (2018) 156

Proceedings of Earth and

Environmental Science, IOP

Conference Series IOP Publishing 1.

Syukur, Fathillah A. and Bagshaw, Dale M.

'Victim-Offender Mediation with

Youth Offenders in Indonesia' (2015)

32 (4) Conflict Resolution Quarterly 390.

Wangi, Y. T., 'Policy of Development for Juvenile Delinquency in the Perspective of Indonesian Criminal Justice System Reform (Study on Institute for Special Development Children LPKA Kutoarjo, Central Java, Indonesia)' (2017) 2, JILS 85.

Windari, Rusmilawati and Widjajanti, Ermania, 'The double track system in sentencing juvenile offenders in Indonesia: Strengths and weaknesses of the Juvenile Criminal Justice System Act 2012' (2015) 23(3) IIUM Law Journal, 501.

\section{ACTS}

Act Number 3, 1997 on Juvenile Court (abolished)

Act Number 11, 2012 on Juvenile Justice System

Act Number 12, 1995 on Correction Service Act Number 39, 1999 on Human Rights

Act Number 23, 2002 on Child Protection Act

Act Number 35, 2014 on the Amendment of the Child Protection Act 